\title{
Is it gamification a tool used for training spanish future teachers? A systematic review of the literature
}

\section{¿es la gamificación una herramienta para la formación de futuros profesores de español? Una revisión sistemática de la literatura}

DOI: $10.46932 / \mathrm{sfjdv} 2 \mathrm{n} 3-052$

Received in: May 1st, 2021

Accepted in: Jun 30th, 2021

\author{
Laura Guerrero-Puerta \\ Professor at Universsity Pablo de Olavide, Seviille, Spain. \\ E-mail: laura.guerrero.puerta@gmail.com
}

\begin{abstract}
This article explores gamification in the field of teaching with the aim of finding out its impact on students of educational sciences in Spain. A systematic review of the literature on gamification in educational studies has been carried out. For this purpose, the bibliographic search engine "Google Scholar" was used, introducing the keywords " Gamificación (gamification)" and "Magisterio (teacher training)", with a result of 105 articles written in Spanish, which have been refined to ensure systematicity resulting in a final sample of 6 articles. The results highlight the effectiveness of gamification as a motivating element for learning in these studies, and the presence of didactics' departments as the main users of those methodologies. However, at the same time, result shown important gaps regarded student's perception about the possible impacts of gamification in their future development as teachers.
\end{abstract}

Keywords: Gamification, Didactics, Pedagogy, University Education, Teaching, Teacher Training.

\section{RESUMEN}

Este artículo explora la gamificación en el ámbito de la enseñanza con el objetivo de conocer su impacto en los estudiantes de ciencias de la educación en España. Se ha realizado una revisión sistemática de la literatura sobre gamificación en los estudios educativos. Para ello se ha utilizado el buscador bibliográfico "Google Scholar", introduciendo las palabras clave "Gamificación" y "Magisterio", con un resultado de 105 artículos escritos en español, que han sido depurados para garantizar la sistematicidad dando lugar a una muestra final de 6 artículos. Los resultados destacan la eficacia de la gamificación como elemento motivador del aprendizaje en estos estudios, y la presencia de los departamentos de didáctica como principales usuarios de dichas metodologías. Sin embargo, al mismo tiempo, los resultados muestran importantes lagunas en cuanto a la percepción de los estudiantes sobre los posibles impactos de la gamificación en su futuro desarrollo como docentes.

Palabras clave: Gamificación, Didáctica, Pedagogía, Educación Universitaria, Enseñanza, Formación del Profesorado. 


\section{INTRODUCTION}

With the arrival of the rhetoric surrounding the knowledge-based society, rooted o the benefits of personal investment and human capital, also came a time of great uncertainty. In this way, new uncertainties aroused about what the future would bring, what the new professions would be like, how much "accumulation" would be necessary to achieve successful integration into that future, and so on.

In the face of this, education was put as the magic recipe to alleviate all the potential negative effects that this future would bring with it. Thus, in the European Union education was proposed as a tool to achieve economic growth and social cohesion; international organizations such as the OECD began to evaluate and classify education systems; and in short time education gained an unprecedented level of attention.

As a consequence of this whole new focus of attention, numerous debates were initiated around the quality of teaching and therefore around the educational systems. This, that seem inevitable in this context, generated a series of gaseous, polluting and redundant discourses, which made it difficult, among other aspects, to advance in understanding of practices that could foster the training of teachers (Novoa, 2009).

In Spain, teacher training has undergone multiple changes as part of a historical development, which has given rise to different institutions in charge of this mission. Thus, we found a (1) first nonuniversity stage in which training through the "Escuelas Normales" and, later, the "Escuelas de Magisterio" stands out. And a second (2) university stage, which began through the "Escuelas Universitarias de Formación del Profesorado de Educación General Básica" and that continues today in the different Faculties of Education Sciences, which are distributed throughout the territory of Spain (González,2008).

Moreover, this evolution has not only been materialised in institutional changes, but these changes have also been accompanied by profound modifications on the meaning and paradigm from which the training process was provided. Authors such as Alvarez \& Gago (2011) state that Spain have gone through four training models, that evolved from the first (1) traditional and then (2) positivists models that began with the Moyano Law and developed until the opening of the Franco regime, passing through a (3) practical model that extends until the gradual entry of the current model (4), based on the acquisition of competences that has been required since the Bologna Plan.

Although, they (ibid) warn that this competence-based model is having an uneven and sometimes deficient implementation, where university lecturers still have a long way to go for been able to provide the experiences needed for those competences to be acquired. 
In this way, what is proposed in this paper is a grounding on the concrete, on the study of delimited practices that can foster this acquisition of competences required in the European framework. Thus, we focus on a methodology, gamification, characterised by a high encouragement in student participation and motivation, seeking to define what effects these techniques can have on teacher training, how they are being used and what progress remains to be made in this field. To this end, in this article we explore a relatively new teaching methodology, Gamification, to find out if and how is this methodology carried out in faculties of education sciences.

\section{BACKGROUND}

This section will first explore the changes in the European Higher Education Area and their impact on teacher education. And will be discussed the teaching methodology of gamification and their possibilities in education. We have chosen to focus on these topics because of their importance in understanding the scope of our study.

\subsection{CHANGES WITHIN INITIAL TEACHER TRAINING AND THE EUROPEAN HIGHER} EDUCATION AREA

As Novoa (2019) points out, there are currently multiple tensions and threats surrounding the school, therefore, it is a crucial moment in the history of teaching, which requires rethinking the way in which teacher training models are configured and carried out. At university level, the teaching and learning model has changed or is in the process of changing. This is a result of changes introduced through the Bologna Plan, that outdated the traditional teaching model, eliminating the figure of the Professor as a figure possessing all the knowledge, and the student body as a tabula rasa.

In view of this, we should ask ourselves questions such as: How can we train the teachers of the future? What tools will they need? How important will be the model we use in this training for their professional development? How can we enrich their professional practice using dynamics of reflexion, innovation and collaboration?

The introduction of the European Higher Education Area, was an important source of knowledge to answer those questions, as it introduced the need for university students not only to acquire knowledge, but also to acquire competences, i.e., skills that would enable them to apply the contents they acquire in lectures, urging them to solve problems, integrate ideas, etc. In this way, what a future teacher had to acquire was a little clearer, competences and skills, but the answer to how has remain much more diffuse (Román, 2010). 
Despite this, however, what seems clear is that the university has a clear responsibility to modify initial teacher training, not only from an ethical point of view, but also in order to meet the requirements that these new plans made clear several years ago. This involves a modification not only of the content, but also of the methods and ways in which it is taught.

\subsection{GAMIFICATION}

If in the previous section we talked about the need to train teachers in competencies, seeking new methods differing from traditional lectures, we now present a methodology, that of gamification which seems appropriate for this purpose.

The gamification methodology emerged at the end of the 2000s, influenced by the development of video games and digital media, having a great acceptance in the field of business and marketing, and integrating itself in an increasingly remarkable way in the educational field. This methodology seeks to increase the motivation levels of the users who participate in it while enhancing the company's or institution's productivity levels (Deterding, Khaled, Nacke \& Dixon, 2011). To this end, it uses the classic characteristics of games (self-motivating and regulating nature), adding to them a series of activities and objectives that promote the acquisition of skills through problem solving (Werbach \& Hunter, 2012).

The literature shows that the use of this methodology in the educational environment can have important benefits, in that it promotes logical thinking, and improves the motivation of students, who being familiar with the virtual environment and video games, recognize this methodology as something playful and attractive, giving cases of students who report a change in terms of recognition of the subject, which can go from being considered difficult or boring, to fun and enjoyable to learn (Manzano-León et.al, 2020; Manzano-León et.al, 2021a; Manzano -León et.al, 2021b).

In addition, if we approach this methodology from the point of view of the teaching activity, this approach, to the extent that it gives a high protagonism in the process to the students, and to the interaction between equals, totally moves away from a traditional conception of teaching, leaving the teacher not as the total protagonist, but as a facilitator of the teaching-learning process (Guerrero-Puerta \& Guerrero, 2021).

\section{METHODS}

In order to create new knowledge on a given topic, a literature search is needed to understand what the current state of the art is, what lines of research are being carried out or what are the topics of greatest interest. Currently, these searches have been described on the basis of three models, which are the narrative literature review, the meta-analysis and the systematic review. 
Of these models, we have selected the systematic review for this chapter, since according to the requirements proposed by Williamson, Lin and Kim (2009), the minimum requirements for carrying out a meta-analysis are not met, and on the other hand, the objective pursued goes beyond answering basic questions on the subject, thus discarding the narrative literature review (Aguilera-Eguía, 2014). Method chosen was PRISMA, due to its proven efficacy in the scientific literature.

To carry out the search, the words "Gamificación (gamification)" and "Magisterio (teaching training)" were entered into Google Scholar. After this, the articles were selected taking into account the following inclusion criteria:
a) Language: Spanish
b) Type of document: Book chapters, conference proceedings, scientific journal articles or teaching project reports.
c) In open format
d) That they were not duplicated
e) They must be related to university teaching in the field of education.
f) They must be studies based in Spanish universities.

\section{RESULTS}

Based on the database search conducted, a total of 104 articles were found, of which, after systematically applying the inclusion requirements described above and eliminating duplicates, we were left with a total of 7 , of which 1 was eliminated because it did not meet the proposed location criteria.

These articles have provided us with interesting data on two main aspects: 1) bibliometrics, and 2) state of the art about the use of Gamification in Teaching enabling degrees. Those are shown in the following section:

\subsection{BIBLIOMETRICS}

In terms of bibliometrics, we can highlight that the scientific production around Gamification and Teaching training is framed in a period between 2017 and 2019, this can be explained by the recent emergence of the term Gamification, which as we mentioned above corresponds to the year 2008 approximately. Moreover, this production peaks between 2018 and 2019, with 5 of the 6 articles included in the selection being published at this date.

Finally, it is noteworthy that the space chosen for the publication of these works has been mostly proceedings books or conference compendiums. And that practically all of them come from authors who 
Table 1: Summary of features of the search results

\begin{tabular}{|c|c|c|c|c|}
\hline Author(s) & $\begin{array}{c}\text { Type of } \\
\text { contribution }\end{array}$ & $\begin{array}{c}\text { Year of } \\
\text { publication }\end{array}$ & Place & Area \\
\hline $\begin{array}{c}\text { López } \\
\text { Carrillo \& } \\
\text { Calonge } \\
\text { García }\end{array}$ & $\begin{array}{l}\text { Conference } \\
\text { paper }\end{array}$ & 2018 & $\begin{array}{l}\text { Alcalá } \\
\text { (SPAIN) }\end{array}$ & $\begin{array}{l}\text { Didactics of } \\
\text { experimental sciences. }\end{array}$ \\
\hline Tabernero & $\begin{array}{l}\text { Educational } \\
\text { project }\end{array}$ & 2018 & $\begin{array}{l}\text { Salamanca } \\
\text { (SPAIN) }\end{array}$ & $\begin{array}{l}\text { Didactics of physical } \\
\text { activity and sports. }\end{array}$ \\
\hline $\begin{array}{c}\text { Alvaréz- } \\
\text { Rosa, et al. }\end{array}$ & $\begin{array}{l}\text { Conference } \\
\text { paper }\end{array}$ & 2017 & $\begin{array}{l}\text { Salamanca } \\
\text { (SPAIN) }\end{array}$ & $\begin{array}{c}\text { Didactics of Spanish and } \\
\text { Foreign Languages }\end{array}$ \\
\hline $\begin{array}{c}\text { Usán \& } \\
\text { Salavera }\end{array}$ & $\begin{array}{l}\text { Conference } \\
\text { paper }\end{array}$ & 2019 & $\begin{array}{l}\text { Zaragoza } \\
\text { (SPAIN) }\end{array}$ & $\begin{array}{c}\text { Educational Psychology } \\
\text { and Developmental } \\
\text { Psychology }\end{array}$ \\
\hline $\begin{array}{l}\text { Rovira- } \\
\text { Collado, } \\
\text { Serna \& } \\
\text { Gallardo }\end{array}$ & $\begin{array}{l}\text { Conference } \\
\text { paper }\end{array}$ & 2018 & $\begin{array}{l}\text { Alicante } \\
\text { (SPAIN) }\end{array}$ & $\begin{array}{c}\text { Didactics of Spanish and } \\
\text { Foreign Languages }\end{array}$ \\
\hline $\begin{array}{c}\text { Prieto } \\
\text { Andreu }\end{array}$ & Article & 2018 & $\begin{array}{l}\text { La Rioja } \\
\text { (SPAIN) }\end{array}$ & $\begin{array}{l}\text { Didactics of physical } \\
\text { activity and sports. }\end{array}$ \\
\hline
\end{tabular}

Source: Own elaboration.

\subsection{STATE OF ART}

After reviewing the selected papers, it has been observed that, although all the studies highlight the benefits of gamification for student motivation, only Usán \& Salavera (2019), and Prieto (2018) report a significant increase in the grades of the group in which this methodology is applied. Furthermore, interestingly, Carrillo and Calogne (2018) point out that, although participation increases in terms of volume, the quality of the assignments delivered does not increase; on the contrary, it may even decrease.

Finally, the role of new technologies in gamification processes stands out, as they are mostly used for the design and implementation of parts or all of the programmed actions. In this way, as Prieto (2015) and Álvarez-Rosa et, al (2017) point out, a whole market of Apps is already created, and that those really ease this process of preparation. 
None of the studies explores participants' perceptions concerning the impact that a exposure to gamification during their teacher training may have on their future teaching, neither do they interrogate the possibility that a first encounter with more participatory methodologies may encourage the use of gamification in their professional practice. This is an important gap in the literature.

\section{CONCLUSIONS:}

The bibliometric results suggest that gamification in educational science teaching is a current topic in the literature, although there is still a scarce production, so it can be considered a line of research development due to the significant increase that has occurred on the subject in the last two years.

Beyond that, gamification, in general terms, has been shown to be a very positive tool in that it increases the participation and motivation of the students who take part in these subjects. However, it may seem paradoxical that the institutions that are usually responsible for training future teachers are not taking up these pedagogical innovations as quickly as might be expected. There is still little production about the use of these methods in teaching training, with the exception of the use of gamification in the area of specific didactics.

It is also significant that there is no reflection on the impact that implementing these techniques has on students with a view to their future as teachers, especially bearing in mind that the studies are carried out by faculties of education. A greater commitment is therefore required from areas such as didactics or pedagogy, which, despite being the areas responsible for teaching new methodologies, seems to play a discreet role in their application. 


\section{REFERENCES}

1. Aguilera-Eguía, R. (2014). ¿Revisión sistemática, revisión narrativa o metaanálisis? Revista de la Sociedad Española del Dolor, 21(6), 359-360.

2. Alvaréz-Rosa, Velasco, Nevot, Marcet \& Castrillo. (2017) El desarrollo de la competencia digital en la universidad: un caso de estudio con Kahoot!. Universidad de Salamanca

3. Álvarez, R. B., \& Gago, A. R. A. (2011). La formación de maestros en España, de la teoría a la práctica. Tendencias pedagógicas, (18), 105-131.

4. Deterding,, Khaled,, Nacke,, \& Dixon, (2011). Gamification: Toward a definition. En ACM CHI Conference on Human Factors in Computing Systems, 2011. Vancouver, Canadá

5. Guerrero-Puerta, L., \& Guerrero, M. (2021). Could Gamification Be a Protective Factor Regarding Early School Leaving? A Life Story. Sustainability, 13(5), 2569.

6. López \& Calonge, (2018). Cómo gamificar una práctica de laboratorio para estudiantes de magisterio. XX simposio sobre enseñanza de la geología. Menorca 2018

7. Manzano-León, A., Camacho-Lazarraga, P., Guerrero-Puerta, M. A., Guerrero-Puerta, L., Alias, A., Trigueros, R., \& Aguilar-Parra, J. M. (2020). Adaptation and validation of the scale of types of users in gamification with the Spanish adolescent population. International Journal of Environmental Research and Public Health, 17(11), 4157.

8. Manzano-León, A., Camacho-Lazarraga, P., Guerrero, M. A., Guerrero-Puerta, L., Aguilar-Parra, J. M., Trigueros, R., \& Alias, A. (2021a). Between level up and game over: A systematic literature review of gamification in education. Sustainability, 13(4), 2247.

9. Manzano-León, A., Camacho-Lazarraga, P., Guerrero-Puerta, M. A., Guerrero-Puerta, L., Alias, A., Aguilar-Parra, J. M., \& Trigueros, R. (2021b). Development and validation of a questionnaire on motivation for cooperative playful learning strategies. International Journal of Environmental Research and Public Health, 18(3), 960.

10. Nóvoa, A. (2019). Tres Tesis sobre el Tercero. Repensando la Formación Docente. Profesorado, Revista De CurríCulum Y FormacióN Del Profesorado, 23(3), 211-222. doi:10.30827/profesorado. v23i3.10280

11. Prieto Andreu, J. M. (2018). Gamificación del aprendizaje y motivación en universitarios. Elaboración de una historia interactiva: MOTORIA-X. Edutec. Revista Electrónica De Tecnología Educativa, (66), 77-92. https://doi.org/10.21556/edutec.2018.66.1085

12. Román, A. (2010) La nueva metodología docente prevista en el espacio europeo de educación superior. Las tecnologías de la información y de la comunicación como soporte de esta nueva docencia: ventajas e inconvenientes. Actas de las I Jornadas sobre Innovación Docente y Adaptación al EEES en las Titulaciones Técnicas, Granada 2010, pp. 241-248

13. Rovira, Serna \& Gallardo (2018). Nuevas estrategias digitales para la Educación Literaria:gamificación y narrativas transmedia en constelaciones literarias. 
14. Tabernero. (2018) elaboración de materiales didácticos para gamificar la asignatura de educación física en primaria (grado maestro) basados en el uso de juegos de mesa, videojuegos y juegos de enigmas. Memoria final proyecto de innovación docente.universidad de salamanca

15. Usán y Salavera. (2019) Utilización de Apps en clase para potenciar la metacognición y el aprendizaje significativo del alumnado.

16. Valda \& Arteaga (2015) diseño e implementación de una estrategia de gamificacion en una plataforma virtual de educación. Proyecto Cer - Universidad La Salle-Bolivia1

17. Werbach, K., \& Hunter, D. (2012). For the win: How game thinking can revolutionize your business. Wharton digital press.

18. Williamson, J.M., Lin, H.M., \& Kim, H.Y. (2009). Using mixed treatment comparisons and metaregression to perform indirect comparisons to estimate the efficacy of biologic treatments in rheumatoid arthritis. Statistics in Medicine, 28. Zalai, D., P 